\section{PERLINDUNGAN KHUSUS BAGI ANAK MENURUT UNDANG-UNDANG NOMOR 35 TAHUN 2014 TENTANG PERUBAHAN ATAS UNDANG-UNDANG NOMOR 23 TAHUN 2002 TENTANG PERLINDUNGAN ANAK ${ }^{1}$ Oleh : Tizza Ihfada Faizal Dalag Patepa ${ }^{2}$ Selviani Sambali ${ }^{3}$ \\ Anna S. Wahongan ${ }^{4}$}

\begin{abstract}
ABSTRAK
\end{abstract}
Tujuan dilakukannya penelitian adalah untuk mengetahui bagaimanakah perlindungan khusus bagi anak menurut Undang-Undang Nomor 35 Tahun 2014 tentang Perubahan Atas Undang-Undang Nomor 23 Tahun 2002 tentang Perlindungan Anak dan bagaimanakah cara memberikan perlindungan khusus bagi anak di mana dengan metode penelitian hukum normatif disimpulkan: 1 . Perlindungan khusus bagi anak menurut Undang-Undang Nomor 35 Tahun 2014 tentang Perubahan Atas UndangUndang Nomor 23 Tahun 2002 tentang Perlindungan Anak diberikan kepada: Anak dalam situasi darurat, Anak yang berhadapan dengan hukum, Anak dari kelompok minoritas dan terisolasi, Anak yang dieksploitasi secara ekonomi dan/atau seksual, Anak yang menjadi korban penyalahgunaan narkotika, alkohol, psikotropika, dan zat adiktif lainnya, Anak yang menjadi korban pornografi, Anak dengan HIV/AIDS, Anak korban penculikan, penjualan, dan/atau perdagangan, Anak korban Kekerasan fisik dan/atau psikis, Anak korban kejahatan seksual, Anak korban jaringan terorisme, Anak Penyandang Disabilitas, Anak korban perlakuan salah dan penelantaran, Anak dengan perilaku sosial menyimpang; dan Anak yang menjadi korban stigmatisasi dari pelabelan terkait dengan kondisi Orang Tuanya. 2. Cara memberikan perlindungan khusus bagi anak dilakukan melalui upaya penanganan yang cepat, termasuk pengobatan dan/atau rehabilitasi secara fisik, psikis, dan sosial, serta pencegahan penyakit dan gangguan kesehatan lainnya dan pendampingan psikososial pada saat pengobatan sampai pemulihan serta pemberian bantuan sosial bagi Anak yang

\footnotetext{
${ }^{1}$ Artikel Skripsi.

${ }^{2}$ Mahasiswa pada Fakultas Hukum Unsrat, NIM. 17071101383

${ }^{3}$ Fakultas Hukum Unsrat, Magister IImu Hukum

${ }^{4}$ Fakultas Hukum Unsrat, Doktor IImu Hukum
}

berasal dari keluarga tidak mampu; danpemberian perlindungan dan pendampingan pada setiap proses peradilan. Kata kunci: anak; perlindungan anak;

\section{PENDAHULUAN}

\section{A. Latar Belakang}

Dari segi hukum internasional, instrumen hukum yang mengatur perlndungan hak-hak anak diatur dalam konvensi P.B.B tentang HakHak Anak (Convention on Rights of The Child) th 1989 yang di tetapkan Resolusi Majelis Umum P.B.B No. 44/ 25 tanggal 20 NOVEMBER 1989, dan telah diratifikasi oleh 191 negara. Sebagai anggota P.B .B Indonesiapun telah meratifikasinya dengan Kepres Nomor 36 Th. 1990. Dengan demikian Konvensi P.B.B tentang Hak Anak tersebut telah menjadi hukum Indonesia dan mengikat seluruh warga Negara Indonesia. Konvensi Hak-Hak Anak merupakan instrumen hukum yang berisi rumusan prinsipprinsip universal dan ketentuan norma-norma hukum mengenai anak. Konvensi Hak-Hak Anak merupakan sebuah perjanjian internasional mengenai hak asasi manusia yang memasukan masing -masing hak sipil dan politik, hak-hak ekonomi, sosial dan budaya. Secara garis besar Konvensi Hak-Hak Anak dapat dikategorikan sebagai berikut: Pertama penegasan hak-hak anak, ke dua perlindungan anak oleh Negara, ke tiga peran serta barbagai pihak (pemerintah, masyarakat, dan swasta) dalam menjamin penghormatan terhadap hak-hak anak, ketentuan-ketentuan hukum mengenai hak-hak anak. $^{5}$

\section{B. Rumusan Masalah}

1. Bagaimanakah perlindungan khusus bagi anak menurut Undang-Undang Nomor 35 Tahun 2014 tentang Perubahan Atas Undang-Undang Nomor 23 Tahun 2002 tentang Perlindungan Anak ?

2. Bagaimanakah cara memberikan perlindungan khusus bagi anak?

\section{Metode Penelitian}

Penelitian hukum yang dilakukan dapat dinamakan penelitian hukum normatif.

\section{PEMBAHASAN}

\footnotetext{
${ }^{5}$ Ibid. hlm. 24.
} 
A. Perlindungan Khusus Bagi Anak Menurut Undang-Undang Nomor 35 Tahun 2014 Tentang Perubahan Atas Undang-Undang Nomor 23 Tahun 2002 Tentang Perlindungan Anak

Undang-Undang Nomor 35 Tahun 2014 Tentang Perubahan Atas Undang-Undang Nomor 23 Tahun 2002 Tentang Perlindungan Anak. Pasal 59 ayat (1) Pemerintah, Pemerintah Daerah, dan lembaga negara lainnya berkewajiban dan bertanggung jawab untuk memberikan Perlindungan Khusus kepada Anak. Ayat (2) Perlindungan Khusus ke pada Anak sebagaimana dimaksud pada ayat(1) diberikan kepada:

a. Anak dalam situasi darurat;

b. Anak yang berhadapan dengan hukum;

c. Anak dari kelompok minoritas dan terisolasi

d. Anak yang dieksploitasi secara ekonomi dan/atau seksual;

e. Anak yang menjadi korban penyalahgunaan narkotika, alkohol, psikotropika, dan zat adiktif lainnya;

f. Anak yang menjadi korban pornografi;

g. Anak dengan HIV/AIDS;

h. Anak korban penculikan, penjualan,dan/atau perdagangan;

i. Anak korban Kekerasan fisik dan/atau psikis;

j. Anak korban kejahatan seksual;

k. Anak korban jaringan terorisme;

I. Anak Penyandang Disabilitas;

m. Anak korban perlakuan salah dan penelantaran;

n. Anak dengan perilaku sosial menyimpang; dan

o. Anak yang menjadi korban stigmatisasi dari pelabelan terkait dengan kondisi Orang Tuanya.

Anak telah menjadi sasaran kepentingan bagi banyak kalangan termasuk untuk tujuan komersial yang merugikan kepentingan terbaik bagi anak. ${ }^{6}$ Betapa saat ini telah terjadi semacam jaringan yang memanfaatkan anak menjadi objeknya. ${ }^{7}$ Anak dijadikan objek untuk

\footnotetext{
${ }^{6}$ Laurensius Arliman S, Op.Cit. hlm. 74 (Lihat Andriyani Mustika Nurwijayati, "Eksploitasi Anak: Perlindungan Hukum Anak Jalanan Dalam Perspektif Hukum Pidana Di Daerah Yogyakarta", Jurnal Jurisprudence Vol. 1 No. 1 (Juli 2012): 208).

${ }^{7}$ Ibid, hIm. 74 (Lihat Benedhicta Desca Prita Octalina, "Perlindungan Hukum Terhadap Anak Korban Eksploitasi Ekonomi", Jurnal Skripsi IImu Hukum Program Kekhususan
}

diperjual-belikan, objek kekerasan, menjadi alat oleh orang dewasa tertentu untuk mencari nafkah dijalan-jalan sebagai anak jalanan, dan sebagainya. ${ }^{8}$

Perlindungan anak adalalah suatu usaha mengadakan kondisi dan situasi yang memungkinkan pelaksanaan hak dan kewajiban anak secara manusiawi positif yang merupakan pula perwujudan adanya keadilan dalam suatu masyarakat. Dengan demikian perlindungan anak harus diusahakan dalam berbagai bidang penghidupan dan kehidupan bernegara, bagi masyarakat dan berkeluarga berdasarkan hukum demi perlakuan benar, adil dan untuk kesejahteraan anak. ${ }^{9}$

Pembangunan nasional yang merupakan proses modernisasi membawa dampak positif maupun negatif. Banyak peristiwa yang menarik perhatian masyarakat akhir-akhir ini yaitu dengan semakin banyaknya perbuatanperbuatan pidana (openbare orde), delinquensi/kenakalan anak-anak atau meningkatnya deviasi serta anak-anak terlantar. ${ }^{10}$ Anak-anak jalanan tak hanya menjadi korban kekerasan, tetapi mereka juga menjadi pelaku kekerasan setelah sebelumnya, mengalami perlakuan yang sama. Mereka belajar dari orang dewasa bahwa hanya dengan kekerasan mereka bisa bertahan hidup. Anakanak tak hanya menjadi korban kerusuhan dan perang, mereka juga menjadi pelakunya. ${ }^{11}$

Untuk itu strategi penanggulangan kejahatan kekerasan ini harus dilandaskan pemahaman tentang unsur-unsur kekerasan yang secara potensial ada dalam nilai-nilai sosial budaya bersangkutan. ${ }^{12}$ Kekerasan

Peradilan dan Penyelesaian Sengketa Hukum, (Yogyakarta: Fakultas Hukum Universitas Atmajaya, 2014), Tidak Dipublikasikan, hlm 3).

${ }^{8}$ Ibid, hlm. 74 (Lihat Netty Endrawati, "Perlindungan Hukum Terhadap Pekerja Anak Di Sektor Informal (Studi Kasus Di Kota Kendiri)", Disertasi IImu Hukum, Program Pasca Sarjana Dotor Ilmu Hukum, (Surabaya: UNTAG, 2011), Tidak Dipublikasikan, hlm 13).

${ }_{9}^{9}$ Moch Faisal Salam, Op.Cit, hlm. 2.

${ }^{10}$ Agung Wahyono dan Siti Rahayu, Peradilan Anak di Indonesia, Sinar Grafika, Jakarta, Januari 1993, hlm. 2. ${ }^{11}$ Agnes Aristiarini dan Maria Hartiningsih, Op.Cit. hlm. 7.

${ }^{12}$ Ariyunus Zai, Mirza Nasution dan Chairul Munadi. Perlindungan Hukum Terhadap Anak Yang Berhadapan Dengan Hukum Dalam Sistem Peradilan Anak (Studi Pada Wilayah Hukum Polres Nias) Jurnal Mercatoria Vol. 4 No. 1 Tahun 2011.hlm. 16 (Lihat Mardjo Reksodiputro, 1997, Kriminologi Dan Sistem Peradilan Pidana, Pusat Pelayanan 
terhadap sesama manusia pada dasarnya berasal dari berbagai sumber. Salah satu kekerasan terhadap satu jenis kelamin tertentu yaitu kekerasan terhadap perempuan disebabkan oleh anggapan gender yang dibentuk oleh masyarakat. Hakim melihat korban kejahatan tidak sebagai objek (melihat bersalahnya korban). Akan tetapi kejahatan harus dilihat secara menyeluruh sebagai suatu proses sosial dimana korban dapat pula dilihat sebagai akibat struktur yang berlaku dalam masyarakat. ${ }^{13}$

Konvensi mengenai Hak-hak anak (Convention on the Rights of Child tahun 1989. Konvensi ini menegaskan hak-hak anak-anak untuk memperoleh perlindungan dan kesempatan serta fasilitas khusus bagi kesehatan dan pertumbuhan mereka secara normal. Konvensi juga membentuk Komite tentang Hak-hak anak yang mengawasi implementasi ketentuan-ketentuan Konvensi dan membahas laporan-laporan yang disampaikan negara-negara anggota. ${ }^{14}$

Pada tanggal 26 Januari 1990 di New York Amerika Serikat, pemerintah Republik Indonesia telah menandatangani Konvensi HakHak Anak, 1989 (Resolusi MU-PBB 44/25). Selanjutnya pada tanggal 25 Agustus 1990 telah dikeluarkan Keputusan Presiden No. 36 Tahun 1990 tentang "Pengesahan Convention on the Rights of the Child". Dengan demikian, dalam upaya melakukan perlindungan anak melalui hukum pidana, sewajarnya kita pun memperhatikan prinsip-prinsip yang tertuang dalam Konensi Hak-Hak Anak tersebut, khususnya yang dinyatakan dalam Artikel 37 dan $40 .^{15}$

Artikel 37 memuat prinsip-prinsip yang dapat dirinci sebagai berikut: ${ }^{16}$

a. Seorang anak tidak akan dikenai penyiksaan atau pidana dan tindakan lainnya yang

Keadilan Dan Pengabdian Hukum, Universitas Indonesia, Jakarta, hlm. 62).

13 Ibid, hlm. 16. (Lihat Mardjo Reksodiputro, 1997, Kriminologi Dan Sistem Peradilan Pidana, Pusat Pelayanan Keadilan Dan Pengabdian Hukum, Universitas Indonesia, Jakarta, hlm. 88).

${ }^{14}$ Boer Mauna, Hukum Internasional (Pengertian Peranan dan Fungsi Dalam Era Dinamika Global, Cetakan ke-3, PT. Alumni. Bandung. 2001, hlm. 606-607.

${ }_{15}$ Moch Faisal Salam, 2002, Op.Cit, hlm. 57.

${ }^{16} \mathrm{lbid}, \mathrm{hlm}, 57-58$. kejam, tidak manusiawi dan merendahkan martabat;

b. Pidana mati maupun pidana penjara seumur hidup tanpa kemungkinan memperoleh pelepasan/pembebasan (without possibility of release) tidak akan dikenakan kepada anak yang berusia di bawah 18 tahun;

c. Tidak seorang anak pun dapat dirampas kemerdekaannya secara melawan hukum atau sewenang-wenang;

d. Penangkapan, penahanan dan pidana penjara hanya akan digunakan sebagai tindakan dalam upaya terakhir dan untuk jangka waktu yang sangat singkat/pendek;

e. Setiap anak yang dirampas kemerdekaannya akan diperlakuan secara manusiawi dan dengan menghormati martabatnya sebagai manusia;

f. Anak yang dirampas kemerdekaannya akan dipisah dari orang dewasa dan berhak melakukan hubungan/kontak dengan keluarganya;

g. Setiap anak yang dirampas kemerdekaannya berhak memperoleh bantuan hukum, berhak melawan/menentang dasar hukum perampasan kemerdekaan atas dirinya di muka pengadilan atau pejabat lain yang berwenang dan tidak memihak serta berhak untuk mendapat keputusan yang cepat/tepat atas tindakan terhadap dirinya itu.

Artikel 40 memuat prinsip-prinsip yang dapat dirinci sebagai berikut: ${ }^{17}$

a. Tiap anak yang dituduh, dituntut atau dinyatakan telah melanggar hukum pidana berhak diperlakukan dengan cara-cara:

1) yang sesuai dengan kemajuan pemahaman anak tentang harkat dan martabatnya;

2) yang memperkuat penghargaan/penghormatan anak pada hak-hak asasi dan kebebasan orang lain;

3) mempertimbangkan usia dan keinginan untuk memajukan/mengembangkan pengintegrasian kembali anak serta mengembangkan harapan anak akan perannya yang konstruktif di masyarakat.

b. Tidak seorang anak pun dapat dituduh, dituntut atau dinyatakan melanggar hukum pidana berdasarkan perbuatan (atau tidak

\footnotetext{
${ }^{17} \mathrm{Ibid}, \mathrm{hlm}$. 58-59.
} 
berbuat sesuatu) yang tidak dilarang oleh hukum nasional maupun internasional pada saat perbuatan itu dilakukan.

c. Tiap anak yang dituduh atau dituntut telah melanggar hukum pidana, sekurangkurangnya memperoleh jaminan-jaminan (hak-hak):

1) untuk dianggap tidak bersalah sampai terbukti kesalahannya menurut hukum;

2) untuk diberitahu tuduhan-tuduhan atas dirinya secara cepat dan langsung (promptly and directly) atau melalui orang tua, wali atau kuasa hukumnya;

3) untuk perkaranya diputus, diadili tanpa penundaan (tidak berlarut-larut) oleh badan/kekuasaan yang berwenang mandiri dan tidak memihak;

a) untuk tidak dipaksa memberikan kesaksian atau pengakuan bersalah;

b) apabila dinyatakan telah melanggar hukum pidana, keputusan dan tindakan yang dikenakan kepadanya berhak ditinjau kembali oleh badan/ kekuasaan yang lebih tinggi menurut hukum yang berlaku;

c) Apabila anak tidak memahami bahasa yang digunakan, ia berhak memperoleh bantuan penerjemah secara Cuma-Cuma (gratis);

d) kerahasiaan pribadi (privacy) nya dihormati/dihargai secara penuh pada semua tingkatan pemeriksaan.

d. Negara harus berusaha membentuk hukum, prosedur, pejabat yang berwenang dan lembaga-lembaga yang secara khusus diperuntukkan/diterapkan kepada anak yang dituduh, dituntut atau dinyatakan telah melanggar hukum pidana, khususnya;

1) menetapkan batas usia minimal anak yang dipandang tidak mampu melakukan pelanggaran hukum pidana;

2) apabila perlu diambil/ditempuh tindakantindakan terhadap anak tanpa melalui proses peradilan, harus ditetapkan bahwa hak-hak asasi dan jaminan-jaminan hukum bagi anak harus sepenuhnya dihormati.

e. Bermacam-macam putusan terhadap anak (antara lain perintah/tindakan untuk melakukan perawatan/pembinaan, bimbingan, pengawasan, program-program pendidikan dan latihan serta pembinaan institusional lainnya) harus dapat jaminan, bahwa anak diperlakukan dengan cara-cara yang sesuai dengan kesejahteraannya dan seimbang dengan keadaan lingkungan mereka serta pelanggaran yang dilakukan.

\section{B. Cara Memberikan Perlindungan Khusus Bagi Anak}

Upaya perlindungan hak-hak asasi manusia, maka bukanlah hal yang mudah dan dapat dilakukan dalam waktu singkat, tetapi merupakan suatu proses yang panjang seperti halnya proses pembangunan itu sendiri. Oleh karena itu upaya tersebut perlu dilakukan secara berkelanjutan dan terpadu oleh semua pihak, yakni pemerintah, organisasi-organisasi politik dan kemasyarakatan maupun berbagai lembaga swadaya masyarakat dan semua lapisan masyarakat. ${ }^{18}$ Suatu masyarakat yang memiliki sistem demokrasi akan melindungi warga negaranya terhadap penganiayaan oleh negara melalui komitmen kolektif pada kesejahteraan ekonomi bersama dan memberi warga negaranya tingkat kehidupan yang membuat mereka hidup bermartabat. ${ }^{19}$

Ditinjau secara garis besar maka dapat disebutkan bahwa perlindungan hukum dapat dibedakan dalam 2 (dua) pengertian yaitu: ${ }^{20}$

1. Perlindungan yang bersifat yuridis yang meliputi perlindungan dalam:

a. Bidang hukum publik;

b. Bidang hukum keperdataan;

2. Perlindungan yang bersifat non yuridis meliputi;
a. Bidang sosial;
b. Bidang kesehatan;
c. Bidang pendidikan.

Berkaitan dengan kerangka perlindungan hukum berikut Philipus M. Hadjon dengan menintikberatkan pada "tindakan pemerintahan" (bestuurshandeling) atau (administrative action) membedakan perlindungan hukum bagi rakyat ke dalam dua macam:

1. Perlindungan hukum represif yaitu perlindungan hukum yang bertujuan untuk

\footnotetext{
${ }^{18}$ Boer Mauna, Op.Cit, hlm. 627.

${ }^{19}$ R.E.,Howard, HAM Penjelajahan Dalih Relativisme Budaya, PT Pustaka Utama Grafiti, Jakarta, 2000, hlm. 319.

${ }^{20}$ Yahya, Ahmad, Zein, Problematika Hak Asasi Manusia, Edisi Pertama. Cetakan Pertama, Liberty. Yoyakarta, 2012, hlm. 51.
} 
menyelesaikan sengketa termasuk di dalamnya adalah penanganan perlindungan hukum bagi rakyat oleh peradilan umum dan peradilan administrasi di Indonesia.

2. Perlindungan hukum Preventif yaitu perlindungan hukum yang bertujuan untuk mencegah terjadinya sengketa. Di dalam perlindungan preventif, rakyat diberi kesempatan untuk mengajukan keberatan (inspraak) atau pendapatnya sebelum keputusan pemerintah mendapat bentuk yang definitif, perlindungan hukum preventif sangat besar artinya bagi tindakan pemerintahan yang didasarkan kepada kebebasan bertindak karena pemerintah terdorong untuk bersikap hati-hati dalam pengambilan keputusan yang didasarkan pada diskresi. ${ }^{21}$

Undang-Undang Nomor 35 Tahun 2014 Tentang Perubahan Atas Undang-Undang Nomor 23 Tahun 2002 Tentang Perlindungan Anak. Pasal 59 A Perlindungan Khusus bagi Anak sebagaimana dimaksud dalam Pasal 59 ayat (1) dilakukan melalui upaya:

a. penanganan yang cepat, termasuk pengobatan dan/atau rehabilitasi secara fisik, psikis, dan sosial, serta pencegahan penyakit dan gangguan kesehatan lainnya;

b. pendampingan psikososial pada saat pengobatan sampai pemulihan;

c. pemberian bantuan sosial bagi Anak yang berasal dari Keluarga tidak mampu; dan

d. pemberian perlindungan dan pendampingan pada setiap proses peradilan.

Pasal 60. Anak dalam situasi darurat sebagaimana dimaksud dalam Pasal 59 ayat (2) huruf a terdiri atas:

a. Anak yang menjadi pengungsi;

b. Anak korban kerusuhan

c. Anak korban bencana alam; dan

d. Anak dalam situasi konflik bersenjata.

Pasal 64 Perlindungan Khusus bagi Anak yang berhadapan dengan hukum sebagaimana dimaksud dalam Pasal 59 ayat (2) huruf b dilakukan melalui:

a. perlakuan secara manusiawi dengan memperhatikan kebutuhan sesuai dengan umurnya;

b. pemisahan dari orang dewasa; c. pemberian bantuan hukum dan bantuan lain secara efektif;

d. pemberlakuan kegiatan rekreasional;

e. pembebasan dari penyiksaan, penghukuman atau perlakuan lain yang kejam, tidak manusiawi serta merendahkan martabat dan derajatnya;

f. penghindaran dari penjatuhan pidana mati dan/atau pidana seumur hidup

g. penghindaran dari penangkapan, penahanan atau penjara, kecuali sebagai upaya terakhir dan dalam waktu yang paling singkat;

h. pemberian keadilan di muka pengadilan Anak yang objektif, tidak memihak, dan dalam sidang yang tertutup untuk umum;

i. penghindaran dari publikasi atas identitasnya.

j. pemberian pendampingan Orang Tua/Wali dan orang yang dipercaya oleh Anak;

k. pemberian advokasi sosial;

I. pemberian kehidupan pribadi;

m. pemberian aksesibilitas, terutama bagi Anak Penyandang Disabilitas;

n. pemberian pendidikan;

o. pemberian pelayanan kesehatan; dan

p. pemberian hak lain sesuai dengan ketentuan peraturan perundang-undangan.

Sistem Peradilan Pidana Anak adalah keseluruhan proses penyelesaian perkara Anak yang berhadapan dengan hukum, mulai tahap penyelidikan sampai dengan tahap pembimbingan setelah menjalani pidana (Pasal 1 angka 1 Undang-Undang Nomor 11 Tahun 2012 tentang Sistem Peradilan Pidana Anak).

Sistem peradilan anak anak adalah suatu sistem penegakan hukum pidana anak yang dilaksanakan secara terpadu oleh 4 (empat) sub-sistem kekuasaan, yaitu: kekuasaan penyidikan, kekuasaan penuntutan, kekuasaan mengadili/menjatuhkan pidana dan kekuasaan eksekusi/pelaksanaan pidana, berdasar hukum pidana materil anak, hukum pidana formal anak dan hukum pelaksanaan pidana anak dan aktivitas dalam penegakan hukum pidana anak ini lebih menekankan pada kepentingan perlindungan anak dan tujuan kesejahteraan anak. $^{22}$

Perbuatan pidana semata menunjuk pada perbuatan baik secara aktif maupun secara pasif, sedangkan apakah pelaku ketika

\footnotetext{
${ }^{22} \mathrm{Ibid}, \mathrm{hlm} .37$.
}

${ }^{21} \mathrm{Ibid}, \mathrm{hlm} .54$. 
melakukan perbuatan pidana patut dicela atau memiliki kesalahan, bukan merupakan wilayah perbuatan pidana, tetapi sudah masuk pada pertanggungjawaban pidana. ${ }^{23}$

Perbuatan pidana adalah perbuatan yang dilarang oleh suatu aturan hukum, larangan mana disertai ancaman (sanksi) yang berupa pidana tertentu, bagi barang siapa yang melanggar larangan tersebut. ${ }^{24}$

Dapat juga dikatakan bahwa perbuatan pidana adalah perbuatan oleh suatu aturan hukum dilarang dan diancam pidana, asal saja dalam pada itu diingat bahwa larangan ditujukan kepada perbuatan (yaitu suatu keadaan atau kejadian yang ditimbulkan oleh kelakuan orang), sedangkan ancaman pidanya ditujukan kepada orang yang menimbulkan kejadian itu. ${ }^{25}$

Kata delik berasal dari bahasa latin, yakni delictum. Dalam bahasa Jerman disebut delict, dalam bahasa Perancis disebut delit dan dalam bahasa Belanda disebut delict. Dalam Kamus Besar Bahasa Indonesia, arti delik diberi batasan sebagai berikut: "perbuatan yang dapat dikenakan hukuman karena merupakan pelanggaran terhadap undang-undang tindak pidana". ${ }^{26}$

Mengingat ciri dan sifat yang khas pada Anak dan demi pelindungan terhadap Anak, perkara Anak yang berhadapan dengan hukum wajib disidangkan di pengadilan pidana Anak yang berada di lingkungan peradilan umum. Proses peradilan perkara Anak sejak ditangkap, ditahan, dan diadili pembinaannya wajib dilakukan oleh pejabat khusus yang memahami masalah Anak. Namun, sebelum masuk proses peradilan, para penegak hukum, keluarga, dan masyarakat wajib mengupayakan proses penyelesaian di luar jalur pengadilan, yakni melalui Diversi berdasarkan pendekatan Keadilan Restoratif. ${ }^{27}$

\footnotetext{
${ }^{23}$ Ali Mahrus, Dasar-Dasar Hukum Pidana, Cetakan Pertama, Sinar Grafika, Jakarta, 2011. hlm. 97

${ }^{24}$ Moeljatno, Asas-Asas Hukum Pidana, Edisi Revisi, PT. Rineka Cipta, Jakarta, 2008, hlm. 59

${ }^{25}$ Ibid.

${ }^{26}$ Leden Marpaung, Asas-Teori-Praktik Hukum Pidana, Sinar Grafika. Cetakan Kedua, Desember, 2005, Jakarta, hIm. 7.

${ }^{27}$ Penjelasan Atas Undang-Undang Republik Indonesia Nomor 11 Tahun 2012 tentang Sistem Peradilan Pidana Anak.
}

Keadilan Restoratif adalah penyelesaian perkara tindak pidana dengan melibatkan pelaku, korban, keluarga pelaku/korban, dan pihak lain yang terkait untuk bersama-sama mencari penyelesaian yang adil dengan menekankan pemulihan kembali pada keadaan semula, dan bukan pembalasan (Pasal 1 angka 6 Undang-Undang Republik Indonesia Nomor 11 Tahun 2012 tentang Sistem Peradilan Pidana Anak).

Diversi adalah pengalihan penyelesaian perkara Anak dari proses peradilan pidana ke proses di luar peradilan pidana. (Pasal 1 angka 7 Undang-Undang Republik Indonesia Nomor 11 Tahun 2012 tentang Sistem Peradilan Pidana Anak).

Penegakan hukum (pidana) meliputi tiga tahap. Tahap pertama, tahap formulasi yakni tahap penegakan hukum in abtracto oleh badan pembuat undang-undang (tahap legislatif). Tahap kedua, tahap aplikasi yakni tahap penerapan hukum pidana oleh para aparat penegak hukum mulai dari kepolisian, kejaksaan sampai pengadilan (tahap yudikatif). Tahap ketiga, tahap eksekusi, yakni tahap pelaksanaan hukum pidana secara konkret oleh aparat-aparat pelaksana pidana (tahap eksekutif atau administrasi). ${ }^{28}$ Sebagai suatu sistem masyarakat, sistem peradilan pidana bertujuan untuk: (a) mencegah masyarakat menjadi korban kejahatan; (b) menyelesaikan kasus kejahatan yang terjadi sehingga masyarakat puas, bahwa keadilan telah ditegakkan dan yang bersalah di pidana; (c) mengusahakan agar mereka yang pernah melakukan kejahatan tidak mengulangi lagi kejahatannya. ${ }^{29}$

Bila mengacu kepada tujuan sistem peradilan pidana itu, bisa diartikan sebagai usaha mencegah dan menanggulangi kejahatan. Di sini pelaku dijatuhi pidana dan direhabilitasi serta dilindunginya korban dan masyarakat. Adapun subsistem yang bekerja sama di dalam sistem peradilan pidana adalah: Kepolisian, Kejaksaan, Pengadilan dan Lembaga Pemasyarakatan. Dari keempat instansi ini yang sangat berkaitan dengan proses dijatuhkannya

\footnotetext{
${ }^{28}$ Aziz Syamsuddin, Tindak Pidana Khusus, Cetakan Pertama, Sinar Grafika, Jakarta, 2011， hlm. 2-3. ${ }^{29}$ Petrus Irwan Panjaitan \& Chairijah, Pidana Penjara Dalam Perspektif Penegak Hukum Masyarakat dan Narapidana, CV. Indhili. Co, Jakarta, 2009, hlm. 56.
} 
pidana penjara adalah kepolisian sebagai penyidik, jaksa penuntut umum dan hakim. Ketiga sub sistem ini selalu identik dengan penegak hukum dalam arti bahwa ketiga instansi ini yang menentukan seseorang itu dijatuhi hukuman atau tidak, utamanya hakim. ${ }^{30}$

Undang-Undang Nomor 35 Tahun 2014 Tentang Perubahan Atas Undang-Undang Nomor 23 Tahun 2002 Tentang Perlindungan Anak. Pasal 65 Perlindungan Khusus bagi Anak dari kelompok minoritas dan terisolasi sebagaimana dimaksud dalam Pasal 59 ayat (2) huruf c dilakukan melalui penyediaan prasarana dan sarana untuk dapat menikmati budayanya sendiri, mengakui dan melaksanakan ajaran agamanya sendiri, dan menggunakan bahasanya sendiri.

Pasal 66 Perlindungan Khusus bagi Anak yang dieksploitasi secara ekonomi dan/atau seksual sebagaimana dimaksud dalam Pasal 59 ayat (2) huruf d dilakukan melalui:

a. penyebarluasan dan/atau sosialisasi ketentuan peraturan perundang-undangan yang berkaitan dengan Perlindungan Anak yang dieksploitasi secara ekonomi dan/atau seksual;

b. pemantauan, pelaporan, dan pemberian sanksi; dan

c. pelibatan berbagai perusahaan, serikat pekerja, lembaga swadaya masyarakat, dan Masyarakat dalam penghapusan eksploitasi terhadap Anak secara ekonomi dan/atau seksual.

Pasal 67. Perlindungan khusus bagi Anak yang menjadi korban penyalahgunaan narkotika, alkohol, psikotropika, dan zat adiktif lainnya sebagaimana dimaksud dalam Pasal 59 ayat (2) huruf e dan Anak yang terlibat dalam produksi dan distribusinya dilakukan melalui upaya pengawasan, pencegahan, perawatan, dan rehabilitasi.

Pasal 67 A. Setiap Orang wajib melindungi Anak dari pengaruh pornografi dan mencegah akses Anak terhadap informasi yang mengandung unsur pornografi.

Pasal 67 B (1) Perlindungan Khusus bagi Anak yang menjadi korban pornografi sebagaimana dimaksud dalam Pasal 59 ayat (2) huruf $f$ dilaksanakan melalui upaya pembinaan,

\footnotetext{
${ }^{30}$ Ibid.
}

pendampingan, serta pemulihan sosial, kesehatan fisik dan mental (2) Pembinaan, pendampingan, serta pemulihan sosial, kesehatan fisik dan mental sebagaimana dimaksud pada ayat (1) dilaksanakan sesuai dengan ketentuan peraturan perundangundangan.

Menurut Penjelasan Atas Undang-Undang Nomor 44 Tahun 2008 tentang Pornografi, Negara Republik Indonesia adalah negara hukum yang berdasarkan Pancasila dan Undang-Undang Dasar Negara Republik Indonesia Tahun 1945 dengan menjunjung tinggi nilai-nilai moral, etika, akhlak mulia, dan kepribadian luhur bangsa, beriman dan bertakwa kepada Tuhan Yang Maha Esa, menghormati kebinekaan dalam kehidupan bermasyarakat, berbangsa, dan bernegara, serta melindungi harkat dan martabat setiap warga negara. Globalisasi dan perkembangan ilmu pengetahuan dan teknologi, khususnya teknologi informasi dan komunikasi, telah memberikan andil terhadap meningkatnya pembuatan, penyebarluasan, dan penggunaan pornografi yang memberikan pengaruh buruk terhadap moral dan kepribadian luhur bangsa Indonesia sehingga mengancam kehidupan dan tatanan sosial masyarakat Indonesia. Berkembangluasnya pornografi di tengah masyarakat juga mengakibatkan meningkatnya tindak asusila dan pencabulan.

Majelis Permusyawaratan Rakyat Republik Indonesia telah mengisyaratkan melalui Ketetapan MPR RI Nomor VI/MPR/2001 tentang Etika Kehidupan Berbangsa mengenai ancaman yang serius terhadap persatuan dan kesatuan bangsa dan terjadinya kemunduran dalam pelaksanaan etika kehidupan berbangsa, yang salah satunya disebabkan oleh meningkatnya tindakan asusila, pencabulan, prostitusi, dan media pornografi, sehingga diperlukan upaya yang sungguh-sungguh untuk mendorong penguatan kembali etika dan moral masyarakat Indonesia. ${ }^{31}$

Banyaknya pekerja/buruh yang di PHK karena ekonomi Indonesia semakin terpuruk. Akibat dari itu anak-anak dari pekerja/buruh yang di PHK, tidak dapat melanjutkan pendidikan. Seharusnya dalam kondisi demikian, anak-anak tersebut menjadi

\footnotetext{
${ }^{31}$ Penjelasan Atas Undang-Undang Nomor 44 Tahun 2008 tentang Pornografi.
} 
kewajiban bagi pemerintah dalam menyediakan sarana pendidikan termasuk pembiayaan sesuai dengan Undang-Undang Republik Indonesia Nomor 23 Tahun 2002. Bila pemerintah tidak memperdulikan kondisikondisi anak-anak tersebut, maka anak-anak itu akan dimanfaatkan baik oleh individu-individu maupun kelompok-kelompok menjadi sarana dalam mencari uang sebanyak-banyaknya dengan jalan bertentangan dengan hukum, yaitu digunakan antara lain sebagai pengamen, pengemis, penjambret, pengedar narkoba, pencuri dalam lain-lain, karena dengan menggunakan anak-anak sebagai sarana tersebut, maka anak-anak itu tidak mendapat perlindungan hukum. Bila anak-anak itu ditangkap oleh pihak berwajib maka anak-anak tersebut akan dikembalikan kepada orang tua atau walinya. Bila diproses hukum, maka pidana yang dijatuhkan sangat ringan dibandingkan dengan orang dewasa serta mendapat perlakuan khusus dari Lembaga Pemasyarakatan yang dipisahkan dari orang dewasa. ${ }^{32}$

Penanganan perkara anak yang tidak dibedakan dengan perkara orang dewasa dipandang tidak tepat karena sistem yang demikian akan merugikan kepentingan anak yang bersangkutan. Anak yang mendapat tekanan ketika pemeriksaan perkaranya sedang berlangsung akan mempengaruhi sikap mentalnya. la akan merasa sangat ketakutan, merasa stres dan akibat selanjutnya ia menjadi pendiam dan tidak kreatif. Dalam dirinya ia merasa dimarahi oleh pejabat pemeriksa dan merasa pula dirinya dijauhi oleh masyarakat. Hal ini yang sangat merugikan kepentingan anak, jangan sampai nantinya setelah perkaranya selesai atau kembali ke masyarakat setelah menjalani masa hukuman, anak menjadi bertambah kenakalannya. Jangan sampai si anak yang pernah tersangkut perkara pidana tidak dapat bergaul dengan baik, sehingga tidak dapat mengabdikan diri kepada nusa dan bangsa. ${ }^{33}$ Oleh karena itu dalam menangani perkara anak terutama bagi para petugas hukum diperlukan perhatian khusus, pemeriksaannya atau perlakuannya tidak dapat disama ratakan dengan orang dewasa, perlu dengan pendekatan-pendekatan tertentu sehingga si anak yang diperiksa dapat bebas dari rasa ketakutan dan rasa aman. ${ }^{34}$

Undang-Undang Nomor 35 Tahun 2014 Tentang Perubahan Atas Undang-Undang Nomor 23 Tahun 2002 Tentang Perlindungan Anak. Pasal 67C Perlindungan Khusus bagi Anak dengan HIV/AIDS sebagaimana dimaksud dalam Pasal 59 ayat (2) huruf $g$ dilakukan melalui upaya pengawasan, pencegahan, pengobatan, perawatan, dan rehabilitasi.

Pasal 68. Perlindungan Khusus bagi Anak korban penculikan, penjualan, dan/atau perdagangan sebagaimana dimaksud dalam Pasal 59 ayat 2 huruf $h$ dilakukan melalui upaya pengawasan, perlindungan, pencegahan, perawatan, dan rehabilitasi.

Pasal 69 Perlindungan Khusus bagi Anak korban Kekerasan fisik dan/atau psikis sebagaimana dimaksud dalam Pasal 59 ayat (2) huruf i dilakukan melalui upaya:

a. penyebarluasan dan sosialisasi ketentuan peraturan perundang-undangan yang melindungi Anak korban tindak Kekerasan; dan

b. pemantauan, pelaporan, dan pemberian sanksi

Pasal 69 Perlindungan Khusus bagi Anak korban Kekerasan fisik dan/atau psikis sebagaimana dimaksud dalam Pasal 59 ayat (2) huruf i dilakukan melalui upaya:

a. penyebarluasan dan sosialisasi ketentuan peraturan perundang-undangan yang melindungi Anak korban tindak Kekerasan; dan

b. pemantauan, pelaporan, dan pemberian sanksi.

Terry E Lawson mengklasifikasikan kekerasan terhadap anak menjadi 4 bentuk, yaitu: emotional abuse (kekerasan emosional), verbal abuse (kekerasaan melalui kata-kata), physical abuse (kekerasan secara fisik), dan sexual abuse (kekerasan seksual). Lebih lanjut menurut Suharto, kekerasan terhadap anak dapat dikelompokkan menjadi:

1. Physical abuse (kekerasan fisik); yaitu penyiksaan, pemukulan, dan penganiayaan terhadap anak, dengan atau tanpa menggunakan benda-benda tertentu, yang

\footnotetext{
${ }^{32}$ H.R. Abdussalam, Hukum Perlindungan Anak, Restu Agung. Jakarta. 2007, hlm. 55-56.

${ }^{33}$ Gatot Supramono, Op.Cit, hlm. 10-11.
}

${ }^{34}$ Ibid, hlm. 11. 
menimbulkan luka-luka fisik atau kematian pada anak.

2. Psychological abuse (kekerasan secara psikis); yaitu penghardikan, penyampaian kata-kata kasar dan kotor, memperlihatkan buku, gambar, dan film pornografi pada anak.

3. Sexual abuse (kekerasan secara seksual); dan yaitu perlakuan pra-kontak seksual antara anak dan orang yang lebih besar, melalui kata, sentuhan, gambar visual, exhibitionism, maupun perlakuan kontak seksual secara langsung antara anak dengan orang dewasa (incest, perkosaan, dan eksploitasi seksual).

4. Social abuse (kekerasan secara sosial); yaitu mencakup penelantaran anak dan eksploitasi anak. Penelantaran anak adalah sikap dan perlakuan orang tua yang tidak memberikan perhatian yang layak terhadap proses tumbuh kembang anak. Misalnya: anak dikucilkan, diasingkan dari keluarga, atau tidak diberikan pendidikan dan perawatan kesehatan yang layak. Sedangkan eksploitasi anak menunjukkan pada sikap diskriminatif atau perlakuan sewenangwenang terhadap anak yang dilakukan keluarga atau masyarakat. ${ }^{35}$

Undang-Undang Nomor 35 Tahun 2014 Tentang Perubahan Atas Undang-Undang Nomor 23 Tahun 2002 Tentang Perlindungan Anak. Pasal 69 A Perlindungan Khusus bagi Anak korban kejahatan seksual sebagaimana dimaksud dalam Pasal 59 ayat (2) huruf j dilakukan melalui upaya:

a. edukasi tentang kesehatan reproduksi, nilai agama, dan nilai kesusilaan;

b. rehabilitasi sosial;

c. pendampingan psikososial pada saat pengobatan sampai pemulihan; dan

d. pemberian perlindungan dan pendampingan pada setiap tingkat pemeriksaan mulai dari penyidikan, penuntutan, sampai dengan pemeriksaan di sidang pengadilan.

Memang ironis bahwa di dalam ranah domestik (rumah tangga), di mana perempuan memberikan tenaga dan pikiran untuk mengurus dan merawat anggota keluarga yang lain, justru di situlah jutaan perempuan mengalami kekerasan yang dilakukan oleh

\footnotetext{
${ }^{35}$ Abu Huraerah, Kekerasan Terhadap Anak, Nuansa Cendekia, Bandung. 2012, hlm. 47-48.
}

orang-orang terdekat mereka. Kondisi di Indonesia tidak jauh berbeda. Menurut Kantor Menteri Pemberdayaan Perempuan Indonesia sangat tinggi. Sekitar 24 juta perempuan atau $11,4 \%$ dari total penduduk Indonesia, pernah mengalami tindakan kekerasan. Tindak kekerasan dominan yang dialami oleh perempuan Indonesia adalah kekerasan domestik atau kekerasan dalam rumah tangga, misalnya penganiayaan, perkosaan, pelecehan atau perselingkuhan yang dilakukan oleh suami. $^{36}$

Berdasarkan ruang lingkupnya kekerasan terhadap perempuan dapat terjadi dalam rumah tangga/keluarga (kekerasan domestik); di masyarakat luas (publik) dan di lingkungan negara (dilakukan oleh/dalam lingkup negara). Kekerasan dalam rumah tangga/keluarga (kekerasan domestik) adalah berbagai bentuk kekerasan yang pelaku dan korbannya memiliki hubungan keluarga/hubungan kedekatan lain, termasuk di sini penganiayaan terhadap isteri, penganiayaan terhadap pembantu rumah tangga, anak kandung dan anak tiri, penganiayaan terhadap orang tua serangan seksual atau perkosaan oleh anggota keluarga terhadap anggota keluarga lainnya. ${ }^{37}$

Undang-Undang Republik Indonesia Nomor 23 Tahun 2004 Tentang Penghapusan Kekerasan Dalam Rumah Tangga. Pasal 5: Setiap orang dilarang melakukan kekerasan dalam rumah tangga terhadap orang dalam lingkup rumah tangganya, dengan cara:
a. kekerasan fisik;
b. kekerasan psikis;
c. kekerasan seksual; atau
d. penelantaran rumah tangga. ${ }^{38}$

\section{PENUTUP}

\section{A. Kesimpulan}

1. Perlindungan khusus bagi anak menurut Undang-Undang Nomor 35 Tahun 2014 tentang Perubahan Atas Undang-Undang Nomor 23 Tahun 2002 tentang Perlindungan Anak diberikan kepada:

\footnotetext{
${ }^{36}$ Moerti Hadiati Soeroso, Op.Cit, hlm. 2.

${ }^{37}$ M. Munandar Sulaeman dan Siti Homzah, Kekekerasan Terhadap Perempuan (Tinjauan Dalam Berbagai Disiplin IImu \& Kasus Kekerasan, Cetakan Pertama, PT. Refika Aditama, Bandung, 2010, hlm. 79-80.

${ }^{38}$ Undang-Undang Republik Indonesia Nomor 23 Tahun 2004 Tentang Penghapusan Kekerasan Dalam Rumah Tangga.
} 
Anak dalam situasi darurat, Anak yang berhadapan dengan hukum, Anak dari kelompok minoritas dan terisolasi, Anak yang dieksploitasi secara ekonomi dan/atau seksual, Anak yang menjadi korban penyalahgunaan narkotika, alkohol, psikotropika, dan zat adiktif lainnya, Anak yang menjadi korban pornografi, Anak dengan HIV/AIDS, Anak korban penculikan, penjualan, dan/atau perdagangan, Anak korban Kekerasan fisik dan/atau psikis, Anak korban kejahatan seksual, Anak korban jaringan terorisme, Anak Penyandang Disabilitas, Anak korban perlakuan salah dan penelantaran, Anak dengan perilaku sosial menyimpang; dan Anak yang menjadi korban stigmatisasi dari pelabelan terkait dengan kondisi Orang Tuanya.

2. Cara memberikan perlindungan khusus bagi anak dilakukan melalui upaya penanganan yang cepat, termasuk pengobatan dan/atau rehabilitasi secara fisik, psikis, dan sosial, serta pencegahan penyakit dan gangguan kesehatan lainnya dan pendampingan psikososial pada saat pengobatan sampai pemulihan serta pemberian bantuan sosial bagi Anak yang berasal dari keluarga tidak mampu; danpemberian perlindungan dan pendampingan pada setiap proses peradilan.

\section{B. Saran}

1. Pemerintah, pemerintah daerah, dan lembaga negara lainnya berkewajiban dan bertanggung jawab untuk memberikan Perlindungan Khusus kepada Anak. Perlindungan terhadap Anak harus mampu memberikan jaminan bagi anak untuk mendapatkan perlakuan dan kesempatan yang sesuai dengan kebutuhannya dalam berbagai bidang kehidupan, sehingga dalam melaksanakan upaya perlindungan terhadap hak anak oleh pemerintah harus didasarkan pada prinsip hak asasi manusia yaitu penghormatan, pemenuhan, dan perlindungan atas hak anak.
2. Pemberian perlindungan khusus bagi anak memerlukan dukungan pemerintah dan pemerintah daerah yang bertanggung jawab menyediakan dana penyelenggaraan perlindungan anak. Pendanaan penyelenggaraan perlindungan anak sebagaimana dimaksud bersumber dari Anggaran Pendapatan dan Belanja Negara dan Anggaran Pendapatan dan Belanja Daerah; dan sumber dana lain yang sah dan tidak mengikat serta dikelola sesuai dengan ketentuan peraturan perundangundangan.

\section{DAFTAR PUSTAKA}

Abdussalam H.R., Hukum Perlindungan Anak, Restu Agung. Jakarta. 2007.

Aristiarini Agnes dan Maria Hartiningsih, Seandainya Aku Bukan Anakmu, (Makalah) Dalam St. Sularto (Editor) Seandainya Aku Bukan Anakmu (Potret Kehidupan Anak Indonesia). PT. Kompas Media Nusantara (Penerbit Buku Kompas) Jakarta, 2000.

Fitriani Rini, Peranan Penyelenggara Perlindungan Anak Dalam Melindungi dan Memenuhi Hak-Hak Anak. Jurnal Hukum Samudra Keadilan Volume 11, Nomor 2 , Juli-Desember 2016 Volume 11, Nomor 2 , Juli-Desember 2016.

Hariri Muhwan Wawan. Pengantar IImu Hukum, Cet. 1. CV. Pustaka Setia Bandung. 2012.

Howard R.E., HAM Penjelajahan Dalih Relativisme Budaya, PT Pustaka Utama Grafiti, Jakarta, 2000.

Huraerah Abu, Kekerasan Terhadap Anak, Nuansa Cendekia, Bandung. 2012.

Huraerah Abu, Kekerasan Terhadap Anak, Cetakan I, Penerbit Nuansa. Bandung, 2006.

Husni Lalu, Pengantar Hukum Ketenagakerjaan Indonesia, Edisi Revisi, PT. RajaGrafindo, Jakarta, 2008.

Kamil Ahmad dan H.M., Fauzan, Hukum Perlindungan Dan Penangkatan Anak Di Indonesia, Edisi. 1. PT. Raja Grafindo Persada, Jakarta, 2008.

Kristi E Poerwandari, Kekerasan Terhadap Perempuan: Tinjauan Psikologi Feministik Kelompok Kerja Convention Wacth, Pusat 
Kajian Wanita dan GenderUniversitas Indonesia, Jakarta. 2000.

Mauna Boer, Hukum Internasional (Pengertian Peranan dan Fungsi Dalam Era Dinamika Global, Cetakan ke-3, PT. Alumni. Bandung. 2001.

Mahrus Ali, Dasar-Dasar Hukum Pidana, Cetakan Pertama, Sinar Grafika, Jakarta, 2011.

Marpaung Leden, Asas-Teori-Praktik Hukum Pidana, Sinar Grafika. Cetakan Kedua. Jakarta, 2005.

Moeljatno, Asas-Asas Hukum Pidana, Edisi Revisi, PT. Rineka Cipta, Jakarta, 2008.

Nuh Muhammad, Etika Profesi Hukum, CV Pustaka Setia, Bandung, 2011.

Panjaitan Irwan Petrus \& Chairijah, Pidana Penjara Dalam Perspektif Penegak Hukum Masyarakat dan Narapidana, CV. Indhili. Co, Jakarta, Juni 2009.

Salam Faisal Moch, Peradilan HAM di Indonesia, Pustaka, Bandung, 2002.

Saraswati Rika, Hukum Perlindungan Anak di Indonesia, Citra Aditya Bakti, Bandung. 2009.

S. Arliman Laurensius. Perlindungan Hukum Terhadap Anak Yang Tereksploitasi Secara Ekonomi Di Kota Padang. Jurnal Arena Hukum Volume 9, Nomor 1, April 2016.

Savitri Niken, HAM Perempuan (Kritik Teori Hukum Feminis Terhadap KUHP), PT. Refika Aditama, Cetakan Pertama, Bandung, 2008.

\section{Peratuan Perundang-Undangan}

Undang-Undang Nomor 35 Tahun 2014 tentang Perubahan Atas Undang-Undang Nomor 23 Tahun 2002 tentang Perlindungan Anak.

Undang-Undang Republik Indonesia Nomor 11 Tahun 2012 tentang Sistem Peradilan Pidana Anak.

Undang-Undang Nomor 44 Tahun 2008 tentang Pornografi.

Undang-Undang Republik Indonesia Nomor 23 Tahun 2004 Tentang Penghapusan Kekerasan Dalam Rumah Tangga.

Lampiran 2 Peraturan Menteri Negara Pemberdayaan Perempuan Dan Perlindungan Anak Republik Indonesia Nomor 01 Tahun 2010 Tentang Standar Pelayanan Minimal Bidang Layanan Terpadu Bagi Perempuan Dan Anak Korban
Kekerasan Ringkasan Standar Pelayanan Minimal (SPM) Bidang Layanan Terpadu Bagi Perempuan Dan Anak Korban Kekerasan. 